\title{
HUBUNGAN KOMPETENSI GURU DENGAN HASIL BELAJAR IPS DI SEKOLAH MENENGAH ATAS
}

\author{
Shinta Candra Karnaningsih, Sulton, Arafah Husna \\ Jurusan Teknologi Pendidikan, Fakultas Ilmu Pendidikan, Universitas Negeri Malang \\ Jalan Semarang 5 Malang 65145 0341-574700 \\ Shintacandra06@gmail.com
}

\section{Article History}

Received: 20 Juni 2020, Accepted: 16 September 2020, Published: 26 Februari 2021

\begin{abstract}
Abstrak
Penelitian ini bertujuan untuk mengetahui hubungan kompetensi guru IPS dengan hasil belajar siswa di Sekolah Menengah Atas Tulungagung. Kompetensi guru adalah suatu hal untuk mendukung kegiatan belajar mengajar. Dimana suatu hasil belajar dapat ditingkatkan melalui guru yang berkompeten. Hasil belajar adalah prestasi belajar yang diraih siswa dalam proses kegiatan belajar mengajar. Data didapatkan melalui data sekunder guru IPS (Ekonomi, Geografi, Sejarah, dan Sosiologi) yang dilaksanakan SMA Tulungagung yaitu Sekolah Menengah Atas Gondang, Sekolah Menengah Atas Pakel, Sekolah Menengah Atas PGRI, dan Sekolah Menengah Atas Islam Al Azhar. Hasil uji hipotesis dalam penelitian ini diperolah hasil korelasi 0,792 dan $p=0,00<0,05$. Sehingga koefisien korelasi sangat tinggi bahwa ada hubungan yang bisa diandalkan. Sehingga ada hubungan antara kompetensi guru IPS dengan hasil belajar di Sekolah Menengah Atas Tulungagung. Penelitian ini mendapatkan hasil jika kompetensi yang dimiliki oleh guru tinggi, maka semakin meningkat pula hasil belajar yang dicapai oleh siswanya.
\end{abstract}

Keyword: Kompetensi Guru; Hasil Belajar

\begin{abstract}
This study aims to determine the relationship of social studies teacher competencies with student learning outcomes in Tulungagung High School. Teacher competence is a matter to support teaching and learning activities. Where a learning outcome can be improved through competent teachers. Learning outcomes are the learning achievements achieved by students in the process of teaching and learning activities. The data was obtained through secondary data from social studies teachers (Economics, Geography, History and Sociology) conducted by Tulungagung High School, namely Gondang High School, Pakel High School, PGRI High School, and Al Azhar Islamic High School. Hypothesis test results in this study obtained the results of a correlation of 0.792 and $p=0.00<0.05$. So the correlation coefficient is so high that there is a reliable relationship. So there is a relationship between the competence of social studies teachers with learning outcomes in Tulungagung High School. This study gets results if the competency of the teacher is high, so the learning outcomes achieved by the students also increase.
\end{abstract}

Keyword: Teacher Competence; Learning outcomes 


\section{PENDAHULUAN}

Pendidikan berguna untuk membantu pelajar mengembangakan dirinya yaitu pengembangan mengenai potensi kecakapan dan karakteristik pribadinya kearah positf, bagi dirinya maupun lingkungannya (Jagantara, Adnyana \& Widiyanti, 2019). Kompetensi ialah keahlian yang dipunyai oleh seorang pengajar berupa aspek kognitif, aspek afektif dan aspek psikomotorik dibutuhkan dalam menjalankan tugasnya sebagai seorang pengajar sehingga bisa melaksanakan tugas dengan terlatih. Maksud utama yang ingin ditempuh dalam proses belajar mengajar adalah hasil belajar. Pada saat ini guru kurang mengevaluasi pada dirinya mengenai keahlian yang di miliki, guru hanya memfokuskan hasil belajar siswa yang rendah karena minat pelajar yang kecil dalam belajar. Rendahnya hasil belajar disebabkan kurangnya ketekunan pebelajar saat belajar dikelas (Marheni, Sujana \& Putra, 2013). Tidak mengerti karakter pelajar, kurang mampu merancang pembelajaran yang menarik, dan kurang mampu mengevaluasi peserta didiknya dengan semestinya (Susanti, 2017).

Empat sekolah di Sekolah Menengah Atas Tulungagung yaitu Sekolah Menengah Atas Gondang, Sekolah Menengah Atas Pakel, Sekolah Menengah Atas PGRI dan Sekolah Menengah Atas Al Azhar, didapatkan data bahwa rendahnya hasil belajar pada mata pelajaran IPS (Ekonomi, Geografi, Sosiologi, Sejarah) masih mendapatkan nilai dibawah Kriteria Ketuntasan Minimum (KKM) dikarekanakan minimalnya kompetensi guru dalam membelajarkan siswanya sehingga siswa tidak mempunyai motivasi dalam belajar. Mutu pembelajaran di Sekolah Menengah Atas sering dibahas karena terdapat masalah dimana mutu pembelajaran yang merata di Indonesia belum tercapai meskipun sudah menggunakan kurikulum yang berlaku (Situmorang, 2013).

Keahlian guru sangat dibutuhkan guna menaikkan hasil belajar siswa. Dalam dunia belajar dan mengajar pengajar dan pelajar ditutut mampu menumbuhkan kemampuan diri dan memiliki kompetesi (Hasanuddin, 2018). Kompetensi guru ialah suatu hal yang bermanfaat untuk menaikkan hasil belajar siswa. Dalam kegiatan belajar mengajar, tanpa adanya keaktifan dari pelajar maka tidak akan mendapatkan tujuan pembelajaran yang maksimal. Keberadaan guru akan mempengaruhi kegiatan pembelajaran dikelas. Keahlian pengajar ialah pengetahuan yang penting untuk pengembangan keterampilan professional guru (Hidayati, Setyosari, \& Soepriyanto, 2018). Pengajar dituntut mampu memotivasi pelajar meningkatkan kemauan belajar pelajar dan mempunyai keahlian yang sama terhadap kemampuannya. Hasil belajar bergantung dengan kemahiran pengajar yang mengajar para pelajar, tak tentu disebabkan oleh sekolah dan struktur kurikulumnya (Hamalik, 2006). Keahlian seorang pengajar sangat diperlukan karena kemahiran mengajar menentukan kesuksesan kegiatan mengajar (Fadhil, 2016).

Pada aktivitas pembelajaran pengajar sebaiknya mampu memahami keahlian dan kesiapan pelajar dalam materi yang akan dipelajari, dan dapat mengetahui kondisi pelajar itu sendiri (Anggraeni, Sulton \& Sulthini, 2018). Guru berkompetensi akan mampu mengolah kelasnya, jadi belajar mengajar para pelajar ada pada keberadaan optimal. Memiliki keahlian untuk mengelola kelas, memiliki pemahaman mengenai materi, metode pembelajaran, dan memahami tujuan-tujuan pembelajaran bisa menaikkan hasil belajar pelajar. Kompetensi pedagogik ialah kemampuan yang menentukan tahap pencapaian cara dan hasil belajar pelajar. Kompetensi pedagogik pengajar adalah kemahiran mengendalikan kelas, yaitu cara guru mengajar dengan melakukan variasi saat aktivitas belajar, keterampilan berhubungan dengan cara untuk menciptakan dan mengendalikan kelas (Rohmawati, 2016). Kompetensi profesional yaitu guru memiliki kemahiran mengerti materi pelajaran yang umum dan banyak. Pendidikan ialah langkah utama yang strategis guna meningkatkan keahlian pengajar agar mampu mengembangkan pembelajaran secara utuh (Ismail Darimi, 2015).

Pengajar professional ialah guru yang mempunyai keahlian menguasai strategi dan teknik dalam perjalanan belajar dengan landasan yang tercantum dalam kemahiran guru (Balqis, Ibrahim\& Ibrahim, 2014). Kompetensi pedagogik adalah keahlian dalam kegaiatan belajar pelajar mencakup pengetahuan 
kenaikan pelajar untuk megaktualisasikan macam-macam keahlian yang dimilikinya. Kompetensi professional yaitu kemampuan pendidik dalam kecakapan mengerti materi pembelajaran umum dan terperinci yang menguatkan proses mendidik pelajar memperoleh kemahiran yang telah ditentukan (Syafmen, 2014).

Penelitian lain yang sudah dilaksanakan oleh penelitian sebelumnya meneliti semua kompetensi yaitu kompetensi pedagogik, kompetensi kepribadian, kompetensi sosial, dan kompetensi professional sehigga kurang memfokuskan pada hasil yang didapatkan. Untuk itulah penelitian ini, peneliti memfokuskan pada dua kompetensi yakni kompetensi pedagogik dan kompetensi professional karena dua keahlian tersebut adalah keahlian yang memang harus dimiliki dan dapat diketahuai guna untuk mengukur hasil belajar pelajar. (Syafmen, 2014) mengatakan bahwa keterampilan seorang pendidik (guru) merupakan keahlian profesi yang tercipta melalalui cara belajar yang wajib ditekuni oleh setiap pendidik dalam mewujudkan pengajar yang professional. Pengajar yang handal menghasilkan pengajaran yang berbobot, hal ini bisa dicapai dengan menciptakan iklim belajar mengajar yang menyenangkan dan mampu meningkatkan kengininan pelajar sehingga siswa mampu mendorong dirinya sendiri untuk mengembangkan kemampuanya. Sebagai tenaga professional, pengajar dituntut mampu menaikkan dan menumbuhkan kompetensi pedagogik dan kompetensi profesionalnya sehingga dapat meninggikan martabat pengajar dan meninggikan hasil belajar yang bermutu pendidikan nasional.

Proses pendidikan, pengalaman, dan pengajaran yang berjalan lama akan mengembangkan pribadi seseorang mempunyai keahlian psikomotorik yang utuh. Guru begitu berguna dalam membuat keadaan yang kondusif untuk siswa terlibat aktif dalam kegiatan belajar baik secara mental maupun fisik (Puspitasari, 2019). Oleh sebab itu, pengajar dituntut mampu memenuhi syarat guna mempunyai keahlian dasar dalam bidangnya. (Mulyasa, 2009) kompetensi dipakai untuk kegiatan belajar sepanjang hanyat yang patut diupayakan. Kompetensi guru adalah kemahiran personal, teknologi, sosial, keilmuan, dan spiritual yang digabungkan menjadi satu sehingga termasuk keahlian materi siswa, aspek kognitif yang mendidik, kenaikkan keahlian dalam masing-masing individu (Mulyasa, 2009).

Keahlian pengajar dipakai untuk menumbuhkan perilaku pendidikan, bukan sekedar mempelajari keterampilan-keterampilan mengajar tertentu, tetapi gabungan pengaplikasian suatu keterampilan dan pemahaman yang saling bertautan dalam wujud perilaku nyata (Mulyasa , 2009). Kenaikkan keahlian dilakukan melalui kegiatan workshop dan asisten (Wildan, 2019). Guru harus mengupayakan agar cara belajar menjadi lebih mudah, sederhana, dan menyenangkan agar siswa memahami materi yang disampaikan oleh pengajar serta dapat mengkontruksikan pengetahuannya sendiri secara aktif, kreatif, dan produktif (Pransiska, Asyhar \& Asrial, 2016). Guru berkompeten ialah pengajar yang mempunyai keahlian sama dengan standar taraf pembelajaran yang telah dittentukan pemerintah (Fahdini, Mulyadi, Suhandani \& Julia, 2016).

Belajar adalah aktivitas manusia yang dibutuhakan bahkan tidak bisa dijauhkan dari kehidupan manusia, bahkan sejak mereka lahir sampai akhir hayat (Puspitasari, 2019). Hasil belajar dipengaruhi oleh kemampuan pelajar dan mutu pengajaran. Kualitas pengajaran adalah profesionalitas dan kemahiran guru. Tercapainya proses belajar siswa dapat dilihat dari hasil belajar (Sirait, 2019). Hasil belajar merupakan capaian yang didapatkan oleh pelajar sesudah melaksanakan aktivitas pembelajaran (Nurdyansyah \& Fitriani, 2018).

Hasil belajar digunakan untuk mengukur keberhasilan peserta didik sesudah mengikuti aktivitas pembelajaran berupa pencapaian hasil berupa huruf ataupun angka (Dimyati \& Mujiono, 2009). (Hamalik, 2006) menjelaskan hasil belajar merupakan satu peralihan kelakuan dan tingkah laku. Hasil belajar harus menunjukkan perubahan atau perbaruan tingkat laku pada pelajar yang positif dan permanen. Siswa tidak tertarik untuk belajar secara individu jika tidak ada guru (Wahyudi, Widiyanti \& Nurhadi, 2018). Pelajar dapat disebut belajar bila terjadi perubahan aspek psikomotorik dimana perubahan tersebut relatif tetap pelajar tidak dikatakan belajar apabila tidak terjadi perubahan positif 
dan relatif tetap dalam dirinya (Nuriadin \& Perbowo, 2013). Hasil belajar adalah suatu kegiatan guna memperoleh ilmu sehingga mampu merubah perilaku individu pelajar.

\section{METODE}

Penelitian ini menggunakan pendekatan kuantitatif. Jenis penelitian ini ialah penelitian korelasional, yaitu jenis penelitian yang bermaksud menganalisis sejauh mana perbedaan pada satu variabel berkaitan dengan variabel lain. Penelitian ini memanfaatkan data sekunder yaitu menggunakan APKG (Alat Penilaian Kinerja Guru) untuk melihat hasil nilai kompetensi pedagogik dan kompetensi profesional guru IPS.

Lokasi penelitian di empat SMA yang ada di Tulungagung yaitu SMA Gondang, SMA Pakel, SMA PGRI dan SMA I Al Azhar. Penelitian ini dilaksanakan bulan Februari - April. Alasan pemilihan lokasi dalam penelitian ini dikarenakan pelajar di SMA Tulungagung nilainya dibawah KKM pada mata pelajaran IPS (Ekonomi, Geografi, Sejarah, Sosiologi). Populasi yang digunakan penelitian ini ialah guru IPS (Ekonomi, Geografi, Sejarah, Sosiologi) di SMA Tulungagung sebanyak 16 guru. Subyek penelitian siswa mengambil dari nilai hasil belajar selama satu semester siswa kelas XI SMA Tulungagung. Sampel penelitian menggunakan non probability sampling. Sampel guru yaitu guru IPS (Ekonomi, Geografi, Sosiologi, Sejarah) kelas XI SMA masing-masing diambil 4 guru dalam satu sekolah. Sementara sampel pelajar yaitu masing-masing sekolah diambil 16 siswa sehingga berjumlah 64 siswa.

Data primer dalam hal ini diperoleh dengan kuisioner yang disebarkan untuk uji coba ke guru di SMA Al Azhar Tulungagung. Jenis data yang dipakai pada penelitian ini terdapat dua jenis yaitu data primer dan data sekunder. Data primer meupakan data yang langsung didapatkan dari sumber pertama. Data sekunder diperoleh melalui dokumen data Alat Penilian Kinerja Guru (APKG) guru IPS (Ekonomi, Geografi, Sejarah, Sosiologi) untuk melihat nilai kompetensi pedagogik dan kompetensi professional guru di empat SMA di Tulungagung. Arsip nilai ulangan akhir semester siswa kelas XI untuk melihat hasil belajar selama satu semester.

Teknik pengumpulan data penelitian ini metode dokumentasi dipakai untuk memperoleh data tentang kompetensi guru di SMA Tulungagung yang dilihat dari Alat Penilaian Kinerja Guru (APKG). Sedangkan hasil belajar didapatkan dari hasil belajar pelajar dari nilai ulangan semester yang didapatkan dari guru mata pelajaran IPS (Ekonomi, Geografi, Sejarah, Sosiologi). Berikut tahap-tahap yang dilalui peneliti dalam pengumpulan data adalah sebagai berikut : (1) menentukan waktu pengambilan data, (2) membuat surat ijin penelitian dari Fakultas (3) memberikan surat penelitian kepada sekolah (4) mempersiapkan data yang akan dibutuhkan (5) pemberian data oleh pihak sekolah (6) menyusun indikator penelitian (6) melakukan uji validitas dan reabilitas pada alat tes yang telah diuji coba (7) memiliki item terbaik untuk kembali disusun menjadi alat tes yang siap untuk disebar (8) mengumpulkan data kemudian ditabulasi dan dianalisis data. Hambatan pada penelitian ini yakni adanya permasalahan pandemic yang mengakibatkan sekolah dan instansi di belajar rumahkan sehingga peneliti kesulitan mencari data penelitian.

\section{HASIL}

Tabel 1 merupakan hasil uji normalitas data dipakai untuk memastikan skor-skor yang didapatkan oleh subyek penelitian dalam distribusi normal, yaitu sebaran skor ada di tengah distibusi skor. Uji normalitas data dilakukan menggunakan rumus Kolmogorov Smirnov. Jika angka signifikansi (p) $>0,05$ dapat disimpulkan bahwa data berdistribusi normal dan apabila nilai signifikansi (p) $<0,05$ data tidak berdistribusi normal. Dari data nilai signifikansi variabel kompetensi guru 0,725>0,05 yaitu data berdistribusi normal. Pada variabel hasil belajar memiliki nilai signifikansi 0,963>0,05 maka data berdistribusi normal. 


\section{Tabel 1 Data Uji Normalitas}

\begin{tabular}{lccc}
\hline \multicolumn{1}{c}{ Variabel } & Signifikansi $(\mathbf{p})$ & Kategori & Keterangan \\
\hline Kompetensi guru & 0,725 & $\mathrm{p}>0,05$ & Normal \\
\hline Hasil belajar & 0,963 & $\mathrm{P}>0,05$ & Normal \\
\hline
\end{tabular}

Berdasarkan tabel 2 uji linieritas digunakan untuk mengetahui apakah dua variabel memiliki hubungan yang linier atau tidak secara signifikan yaitu hubungan kompetensi guru IPS dengan hasil belajar. Uji linearitas dilakukan dalam penelitian menggunakan test of linearity. Hubungan antar variabel dikatakan linier apabila angka signifikansi yang diperoleh $(\mathrm{p}<0,05)$ atau $(\mathrm{p}>0,05)$.

\section{Tabel 2 Data Uji Linieritas}

\begin{tabular}{cccc}
\hline Pengukuran & Signifikansi $(\mathbf{p})$ & Kategori & Keterangan \\
\hline Sig. linierity & 0,001 & $\mathrm{P}<0,05$ & Linier \\
\hline Deviation from linierity & 0,128 & $\mathrm{P}>0,05$ & Linier \\
\hline
\end{tabular}

Berdasarkan hasil perhitungan linieritas didapatkan nilai sig.linierity sebesar 0,001 yang berarti nilai kurang dari $0,05(\mathrm{p}<0,05)$ dan nilai deviation from linierity sebesar 0,128 berarti nilai ini lebih besar dari 0,05 ( $p>0,05)$. Sehingga hasil perhitugan diatas dapat disimpulkan variabel kompetensi guru IPS dan hasil belajar membentuk garis lurus atau linier pada kurva kompetensi guru (variabel X) dan hasil belajar (variabel Y).

\section{Tabel 3 Data Hasil Uji Hipotesis}

\begin{tabular}{ccc}
\hline Koefisien Korelasi & Signifikansi (p) & Keterangan \\
\hline 0,792 & 0,00 & $\mathrm{P}<0,05$ \\
\hline
\end{tabular}

Dapat dilihat tabel 3 merupakan data hasil uji hipotesis dalam penelitian untuk mengetahui hubungan antara keahlian pengajar IPS dengan hasil belajar di SMA Tulungagung yaitu menggunakan uji hipotesis korelasi pearson. Berdasarkan hasil analisis yang peneliti dapatkan menggunakan Pearson Correlation diperolah hasil korelasi 0,792 dan $p=0,00<0,05$. Sehingga koefisien korelasi sangat tinggi bahwa ada hubungan yang bisa diandalkan. Sehingga Ha diterima dan Ho ditolak, sehingga ada hubungan antara kompetensi guru IPS dengan hasil belajar di SMA Tulungagung. Koefisien korelasi yang bernilai positif bahwa ada hubungan positif antara kompetensi guru IPS dengan hasil belajar.

\section{PEMBAHASAN}

Dari data lapangan berupa data tentang hubungan keahlian pengajar IPS dengan hasil belajar di Sekolah Menengah Atas Tulungagung dengan hasil belajar pelajar pada mata pelajaran Ekonomi, Geografi, Sejarah, dan Sosiologi kelas XII dalam empat Sekolah Menengah Atas sejumlah 64 siswa. Sebelum instrumen angket dipakai penelitian maka perlu diuji tingkat validitas dan realibitasnya. Jumlah yang digunakan dalam uji coba instrumen sebanyak 9 item pernyataan terdiri dari 9 item pernyataan tentang kompetensi pedagogik dan kompetensi profesional. Sedangkan hasil belajar diambil dari nilai ulangan semester. Hasil uji coba instrumen dinyatakan valid.

Dari data skor, 16 responden perhitungan kompetensi guru IPS ( Ekonomi, Geografi, Sejarah, Sosiologi) memperoleh hasil nilai mean 27,88 dan standar deviasi 4,965. Nilai deskripsi skala yang didapatkan nilai minimum yaitu 20 dan nilai maksimum 36. Dinyatakan sebanyak 16 responden bahwa 10 orang (62\%) pengajar IPS (Ekonomi, Geografi, Sejarah, Sosiologi) di Sekolah Menengah Atas Tulungagung memiliki keahlian yang tinggi dan sebanyak 6 orang (38\%) guru IPS (Ekonomi, Geografi, Sejarah, Sosiologi) di Sekolah Menengah Atas Tulungagung memiliki keahlian yang rendah. Sehingga sebagian besar guru IPS (Ekonomi, Geografi, Sejarah, Sosiologi) di Sekolah Menengah Atas 
Tulungagung mempunyai keahlian yang tinggi yaitu kompetensi pedagogik dan kompetensi professional.

Dari perhitungan hasil belajar pelajar di SMA Tulungagung sebanyak 64 siswa memperoleh nilai mean 76,73 dan standar deviasi 7,196. Nilai minimum 60 dan nilai maksimum 90. Sebanyak 32 orang (50\%) di Sekolah Menengah Atas Tulungagung memiliki hasil belajar yang tinggi dan sebanyak 32 orang (50\%) siswa di Sekolah Menengah Atas Tulungagung memiliki hasil belajar yang rendah. Sehingga perhitungan menyatakan separuh siswa di Sekolah Menengah Atas Tulungagung memiliki hasil belajar yang tinggi dan separuh memiliki hasil belajar yang rendah.

Hasil analisis yang didapatkan oleh peneliti terhadap skor keahlian guru pada guru di Sekolah Menengah Atas Tulungagung didapatkan bahwa sebagian besar guru mempunyai kompetensi yang tinggi. Hal ini dibuktikan melalui hasil perhitungan yang menyatakan rata-rata pengajar di Sekolah Menengah Atas Tulungagung mempunyai keahlian yang tinggi. Sehingga dapat dikatakan bahwa guru di Sekolah Menengah Atas Tulungagung memiliki kompetensi yang tinggi. Hasil belajar pelajar di Sekolah Menengah Atas Tulungagung didapatkan hasil separuh siswa memiliki hasil belajar tinggi dan separuh memiliki hasil belajar yang rendah.

Berdasarkan analisis korelasi didapatkan hasil bahwa Ha diterima dan Ho ditolak yaitu ada hubungan yang positif antara kompetensi guru IPS (Ekonomi, Geografi, Sejarah, Sosiologi) dengan hasil belajar di SMA Tulungagung. Korelasi yang terjadi antara keahlian pengajar IPS (Ekonomi, Geografi, Sejarah, Sosiologi) hasil belajar tergolong dalam korelasi yang sangat tinggi bahwa ada hubungan yang bisa diandalkan. Diartikan sebagai korelasi dimana hubungan yang ada kompetensi guru dengan hasil belajar merupakan sebuah hubungan yang dapat dipercaya. Kompetensi guru didapatkan dari faktor dalam dan faktor luar, faktor dalam yaitu faktor dari dalam diri sendiri guru tersebut adanya motivasi dalam melakukan pekerjaan. Sedangkan dari faktor luar yaitu faktor luar berupa pendidikan atau keahlian dalam membimbing, atau jenis pelatihan yang pernah diikuti. Berdasarkan hasil penelitian disimpulkan bahwa semakin tinggi kompetensi yang dimiliki oleh guru semakin meningkat pula hasil belajar yang didapatkan oleh siswanya.

Kompetensi guru didapatkan dari faktor dalam dan luar, faktor dalam yaitu faktor dari dalam diri guru tersebut adanya motivasi dalam melakukan pekerjaan. Sedangkan faktor luar yaitu faktor berupa pendidikan atau keahlian dalam mengajar, jenis pelatihan yang pernah dijalani. Faktor itu tidak bisa dipisahkan dalam membangun kemahiran pengajar dalam menjalankan aktivitas belajar.

Hal ini dikukuhkan dengan penelitian lain yang diljalankan oleh Aroma Fatimah Azahra (2015) yang diketahui bahwa kompetensi guru sangat diperlukan guna menaikkan hasil belajar siswa. Tingkat kompetensi guru terhadap hasil belajar siswa pada mata pelajaran IPS di SMP Plus Al-Kautsar Malang bisa dikatakan cukup bagus dilihat dari perolehan presentasi diagram batang yang semuanya menempatkan keahlian guru (kompetensi pedagogik, kompetensi kepribadian, kompetensi sosial, dan kompetensi professional). Sehingga keahlian guru sangat diperluakan pada aktivitas pembelajaran, bukan hanya satu kompetensi saja yang harus dipahami tetapi diusahakan mempunyai keempat keahlian tersebut. Penelitian dijalankan oleh Sultan Hasanuddin (2018) dimana nilai koefisien regresi sebesar 0, 298 dan nilai signifikan sebesar 0,001 dinyatakan lebih kecil dari taraf kepercayaan 0,05 sehingga keahlian pengajar berpengaruh positif dan signifikan terhadap prestasi belajar di MA DDI Ponre Kabupaten Bone sehingga keahlian guru yang tinggi dapat menaikkan hasil belajar yang tinggi.

Penelitian lain oleh Wahyu Bagja Sulfemi (2016) diperoleh hasil memiliki hubungan yang kuat karena persepsi pelajar tentang keahlian pengajar mata pelajaran sejaarah akan berhubungan langsung dengan pelajar. Satu aspek yang mengakibatkan hasil belajar pelajar di SMA Negeri 1 Pamijahan Kabupaten Bogor yakni kepandaian pengajar dalam mendidik dan membina pelajar kearah yang lebih bagus. Begitu juga dengan penelitian ini memperoleh hasil bahwa hubungan kuat antara keahlian 
pengajar dengan hasil belajar. Karena kompetensi guru ialah kompetensi pedagogik dan kompetensi profesional sangat berhubungan dengan hasil belajar siswa. Kompetensi guru yang tinggi memberikan hubungan meningkatkan hasil belajar pelajar.

Melalui data statistik yang sudah didapatkan pada penelitian ini, diketahui jika terdapat hasil positif antara kompetensi guru dengan hasil belajar pada mata pelajaran IPS (Ekonomi, Geografi, Sejarah, Sosiologi) di Sekolah Menengah atas Gondang, Sekolah Menengah Atas Pakel, Sekolah Menengah PGRI dan Sekolah Menengah Atas Islam Al Azhar. Dimana kompetensi guru sangat berhubungan dengan hasil belajar siswa. Adanya peningkatan hasil belajar pelajar dikarenakan kompetensi guru yang tinggi. Peningkatan hasil belajar pelajar yang di damping oleh seoarang pengajar yang mempunyai keahlian yang bagus karena pengajar yang berkompetensi dapat membuat pembelajaran semakin menyenangkan, dapat mengatur kelas dan dapat membuat pembelajaran lebih bervariasi sehingga pembelajaran dikelas terasa asik sehingga memotivasi pelajar untuk belajar.

Dalam (Mulyasa, 2009) menyebutkan keahlian pengajar yaitu kombinasi dari individu, pengetahuan, teknologi, cara bermasyakat, dan keagaamaan membangun kemampuan dasar keahlian pengajar yang termasuk keterampialan pemahaman materi kepada pebelajar, belajar dengan terbimbing, peningkatan kepribadian, dan profesionalisme. Kriteria pengajar yang mempunyai kompetensi baik ialah pengajar yang mempunyai keahlian dalam mengatur pembelajaran pelajar dan memiliki kemampuan keahlian memahami materi pelajaran yang luas, berakhlak mulia, dan mampu berkomunikasi dengan pelajar / wali murid / warga sekolah.

\section{SIMPULAN}

Hasil penelitian menjelaskan bahwa guru IPS (Ekonomi, Geografi, Sejarah, Sosiologi) mempunyai kompetensi tinggi, pelajar di Sekolah Menengah Atas Tulungagung memiliki hasil belajar yang tinggi. Terdapat hubungan yang positif antara kompetensi guru IPS (Ekonomi, Geografi, Sejarah, Sosiologi) dengan hasil belajar siswa di Sekolah Menengah Atas Tulungagung yang menunjukkan semakin tinggi kompetensinya maka hasil belajarnya akan semakin meningkat. Hal ini mengukuhkan bahwasannya kompetensi guru sangat dibutuhkan dalam menjalankan pembelajaran guna menaikkan hasil belajar pelajar.

\section{DAFTAR RUJUKAN}

Anggraeni, R., Sulton., \& Sulthoni. (2019). Pengaruh Multimedia Tutorial Terhadap Hasil Belajar Bahasa Indonesia. Jurnal Kajian Teknologi Pendidikan, 2(2), 96-101. Retrieved from : https://doi.org/10.17977/um038v2i22019p096

Azzahra, A. F. (2015). Pengaruh Kompetensi Guru Terhadap Hasil Belajar Siswa Pada Mata Pelajaran Ilmu Pengetahuan Sosial di SMP Plus Al-Kautsar Blimbing Malang. Skripsi diterbitkan. Malang : Program Studi Pendidikan Ilmu Pengetahuan Sosial Universitas Islam Negeri Maulana MalikIbrahim Malang.

Balqis, P., Ibrahim, N. U., \& Ibrahim, S. (2014). Kompetensi pedagogik guru dalam meningkatkan motivasi belajar siswa pada SMPN 3 Ingin Jaya Kabupaten Aceh Besar. Jurnal Administrasi Pendidikan: Program Pascasarjana Unsyiah, 2(1), 25-38. Retrieved from : http://erepository.unsyiah.ac.id/JAP/article/view/2497

Darimi, I. (2015). Peningkatan Kompetensi Pedagogik Guru PAI dalam Pembelajaran. Jurnal Mudarrisuna: Media Kajian Pendidikan Agama Islam,5(2), 309-324. Retrieved from : https://doi.org/10.22373/JM.V5I2.630

Dimyati dan Mujiono. 2006. Belajar dan Pembelajaran. Jakarta: Rineka Cipta. 
Fadhil, M. (2016). Pengaruh Kompetensi Sumber Daya Manusia Terhadap Kinerja Pegawai Pada Balai Latihan Kerja Industri Makassar. Perspektif: Jurnal Pengembangan Sumber Daya Insani, 1(1), 70-81. Retrieved from : www.journal.unismuh.ac.id/perspektif

Fahdini, R., Mulyadi, E., Suhandani, D., \& Julia, J. (2014). Identifikasi Kompetensi Guru sebagai Cerminan Profesionalisme Tenaga Pendidik di Kabupaten Sumedang. Mimbar Sekolah Dasar, 1(1), 33-42. Retrieved from : https://doi.org/10.17509/mimbar-sd.v1i2.874

Hamalik, Oemar (2006), Pendidikan Guru Berdasarkan Pendekatan Kompetensi, Jakarta: Bumi Aksara.

Hasanuddin, S. (2018). Pengaruh Kompetensi Guru Terhadap Prestasi Belajar Siswa Pada Mata Pelajaran Sejarah Kebudayaan Islam Di MA DDI Ponre Kabupaten Bone. At-Ta'lim: Media Informasi Pendidikan Islam, 16(1), 146-161. Retrieved from : https://ejournal.iainbengkulu.ac.id/index.php/attalim/article/view/826

Hidayati, N., Setyosari, P., \& Soepriyanto, Y. (2018). Kompetensi Technological Pedagogical Content Knowledge (TPACK) Guru SOSHUM Setingkat SMA. Jurnal Kajian Teknologi Pendidikan, 1(4), 291-298. Retrieved from : https://doi.org/10.4018/978-1-5225-7918-2.ch016

Jagantara, I. M. W., Adnyana, P. B., \& Widiyanti, N. L. P. M. (2014). Pengaruh Model Pembelajaran Berbasis Proyek (Project Based Learning) Terhadap Hasil Belajar Biologi Ditinjau Dari Gaya Belajar Siswa SMA. Jurnal Pendidikan dan Pembelajaran IPA Indonesia, 4(1). 1-13. Retrieved from http://garuda.ristekbrin.go.id/documents/detail/259538

Marheni, N. L. G., Sujana, I. W., \& Putra, D. K. N. S. (2013). Penerapan Model Pembelajaran Kooperatif Tipe STAD Untuk Meningkatkan Keaktifan Dan Hasil Belajar IPS Kelas V Sd No. 8 Padangsambian Denpasar. MIMBAR PGSD Undiksha, 1(1), 1-10. Retrieved from : https://doi.org/http://dx.doi.org/10.23887/jjpgsd.v1i1.1438

Martini,Yamin, dan Maisyah (2010) Standarisasi Kinerja Guru. Jakarta: GP Press.

Mulyasa. 2009. Standar Kompetensi dan Sertifikasi Guru. Bandung: PT Remaja Rosdakarya.

Nurdyansyah, N., \& Fitriyani, T. (2018). Pengaruh Strategi Pembelajaran Aktif Terhadap Hasil Belajar Pada Madrasah Ibtidaiyah. E-Print UMSIDA 1(2), 929-930. Retrieved from : http://eprints.umsida.ac.id/id/eprint/1610

Nuriadin, I., \& Perbowo, K. S. (2013). Analisis korelasi kemampuan berpikir kreatif matematik terhadap hasil belajar matematika peserta didik SMP Negeri 3 Lurangung Kuningan Jawa Barat. Infinity Journal, 2(1), 65-74. Retrieved from : https://doi.org/10.22460/infinity.v2i1.25

Pransiska, S., Asyhar, R., \& Asrial, A. (2016). Pengaruh Penerapan Model Pembelajaran Group Investigation dan Motivasi Terhadap Hasil Belajar Siswa Kela VII SMP Dalam Pembelajaran IPA Terpadu Pada Materi Asam, Basa dan Garam. Edu-Sains: Jurnal Pendidikan Matematika dan Ilmu Pengetahuan Alam, 5(2). 1-7. Retrieved from : https://onlinejournal.unja.ac.id/index.php/edusains/article/view/3390

Puspitasari, S. (2019). Upaya Meningkatkan Hasil Belajar Ipa Dengan Menggunakan Model Pembelajaran Think Pair Share. Jurnal Global Edukasi,3(1), 55-60. Retrieved from : http://jurnal.goretanpena.com/index.php/GJE

Rohmawati, R. (2016). Kompetensi Pedagogik Guru Pendidikan Kewarganegaraan Dalam Membangun Kecerdasan Berdemokrasi Warga Negara. Skripsi diterbitkan. Surakarta : Program Studi Pendidikan Kewarganegaraan Universitas Sebelas Maret Surakarta.

Sagala, Saiful. 2009. Kemampuan Profesional Guru dan Tenaga Kependidikan. Bandung: Alfabeta

Sirait, R. (2019). Upaya Meningkatkan Hasil Belajar Bahasa Inggris Dengan Menggunakan Model Pembelajaran Think Talk Write. Jurnal Global Edukasi,3(1), 43-48. Retrieved from : http://jurnal.goretanpena.com/index.php/JGE/article/view/337

Situmorang, M. (2014). Pengembangan Buku Ajar Kimia SMA Melalui Inovasi Pembelajaran Dan Integrasi Pendidikan Karakter Untuk Meningkatkan Hasil Belajar Siswa. Prosiding SEMIRATA 2013, 1(1). 237-246. Retrieved from : https://jurnal.fmipa.unila.ac.id/semirata/article/view/817 
Susanti, S. (2018). Kompetensi Pedagogik Yang Dimiliki Guru Kelas Tinggi Di Mi Ma'arif Nu 2 Pancasan Ajibarang. Jurnal Penelitian Agama, 19(2), 1-19. Retrieved from : https://doi.org/10.24090/jpa.v20i2.2019.pp315-336

Sulfemi, W. B. (2016). Hubungan Persepsi Peserta Didik Tentang Kompetensi Guru Mata Pelajaran Sejarah Dengan Hasil Belajar Peserta Didik Mata Pelajaran Sejarah Di Kelas X SMA Negeri 1 Pamijahan Kabupaten Bogor. Jurnal Fascho, 5(2), 52-70. Retrieved from : https://d1wqtxts1xzle7.cloudfront.net/58227178/Jurnal_fASCHO_edisi_2._2016__OKTOBER. pdf?15480

Syafmen, W. (2014). Studi Tentang Dampak Sertifikasi Terhadap Kompetensi Pedagogik Dan Profesional Guru Matematika Di SMP N Kota Jambi. Edumatica: Jurnal Pendidikan Matematika, 4(01), 1-7. Retrieved from : $\quad$ https://www.onlinejournal.unja.ac.id/edumatica/article/view/1583

Wahyudi, M. A., Widiyanti, W., \& Nurhadi, D. (2018). Kecerdasan Visual Spasial Dan Kemandirian Belajar Pada Hasil Belajar Mata Pelajaran Gambar Teknik Di SMK. Teknologi Dan Kejuruan: Jurnal Teknologi, Kejuruan, Dan Pengajarannya,41(2), 101-109. Retrieved from : https://doi.org/10.17977/um031v42i22018p101

Wildan, W. (2019). Peningkatan kompetensi profesional guru melalui metode pendampingan. Transformasi: Jurnal Pengabdian Masyarakat, 15(1), 35-43. Retrieved from : https://doi.org/10.20414/transformasi.v15i1.1024 